Zbornik Instituta za kriminološka

i sociološka istraživanja

2020 / Vol. XXXIX / 2-3 / 109-126

Pregledni naučni rad

Primljeno: 14. oktobra 2020. godine

Prihvaćeno: 27. oktobra 2020. godine

DOI: $10.47152 /$ ziksi2020237

UDK: $316.344 .26 / .27$

\title{
PREKARIJAT I NEKA PITANJA DRUŠTVENE STRUKTURE I DRUŠTVENIH NEJEDNAKOSTI*
}

\author{
Aleksandra Marković*
}

\begin{abstract}
Opravdanost uvođenja još uvek relativno novog pojma prekarijata $u$ naučni fond znanja je pitanje koje zahteva posebnu analizu $i$ argumentaciju. No, bez obzira na to sa kojih stanovišta polazimo, pripadnici prekarijata (ili pojedinaca koji se nalaze $u$ izrazito prekarnom položaju u savremenim društvima) ne levitiraju nezavisno jedni od drugih $i$ od ostalih društvenih grupacija. Stoga je cilj ovog rada bio pre svega da pruži čitaocima kratki prikaz kompleksnosti ispitivanja društvene strukture $i$ sistema, pre svega kroz pregled osnovnih teorijskih pravaca proučavanja društvene stratifikacije $i$ nejednakosti, te da otvori pitanje da li i na koji način bi prekarijat mogao biti epistemološki ali $i$ metodološki ispitivan u proučavanjima društvene stratifikacije. Ponuđen je prikaz, kao i kritika, jednog od, za sada, najuticajnijih empirijskih istraživanja društvene strukture, $u$ kojem je prekarijat prepoznat kao jedna od društvenih grupa koji sačinjavaju strukturu britanskog društva (BBC's Great British Class Survey, 2011).
\end{abstract}

KLJUČNE REČI: Prekarijat / Društvena struktura / Društvena stratifikacija / Društvene nejednakosti

\footnotetext{
* Tekst je nastao kao rezultat rada na projektu „Kriminal u Srbiji: fenomenologija, rizici i mogućnost socijalne intervencije“ (broj 47011) finansiran od strane Ministarstva prosvete, nauke i tehnološkog razvoja Republike Srbije.

* Istraživač saradnik u Institutu za kriminološka i sociološka istraživanja, Beograd. E-mail: aleksandra.markovic1@hotmail.com
} 


\author{
Zbormik IKSI, 2-3/2020 - A. Marković \\ „Prekarijat i neka pitanja društvene strukture i društvenih nejednakosti”, (str. 109-126)
}

\title{
UVOD $^{1}$
}

Kao „pojmovni otac“ prekarijata uzima se britanski ekonomista Guy Standing, koji u globalizaciji nalazi osnov za nastajanje prekarijata. Za razliku od uobičajenog stanovišta da sa globalizacijom dolazi do deregulacije, Standing tvrdi da je na delu proces re-regulacije ${ }^{2}$ (Standing, 2011: 26). Globalizacija nije dovela do nestanka klasa ${ }^{3}$, već je doprinela fragmentaciji nacija i klasa. Danas su nam, veli Standing, možda potrebni novi termini da bismo opisali tu novu klasnu raznovrsnost. Iako pripadnici prekarijata nisu homogena grupa, povezuje ih to što je njihov rad instrument preživljavanja, oportunizam (da uzmu sve što mogu) i nesigurnost i to u znatno većoj meri nego što je to bilo karakteristično za proletarijat. Za ovog autora, prekarijat je „klasa u nastajanju“, on još uvek nije postao klasa za sebe (Standing, 2011).4 Prekarijat se sastoji od individua kojima nedostaje sedam oblika radne sigurnosti (labour-related security) za koje su se sindikati i radničke partije izborile nakon Drugog svetskog rata: sigurnost tržišta rada (labour market security), sigurnost zaposlenja (employment security), sigurnost posla (job security), sigurnost na poslu (work security), unapređenje veština (skill reproduction security), sigurnost prihoda (income security), sigurnost predstavljanja (representation security) (Ibid: 10-11, v. Marković, 2018). U Standingovom određenju prekarijata, tri dimenzije određuju prekarijat: položaju na tržištu rada, karakteristični odnose (re)distribucije i odnos prema/od strane države. Prekarijat čine tri velike grupacije: jednu sačinjavaju nekadašnji pripadnici radničke klase, koji su „skliznuli“ u prekarijat, drugu mladi nezaposleni i „prekvalifikovani“, a treću tzv. nepripadajući građani5 (Standing, 2011, Marković, Jovanović-Ajzenhamer, 2018). ${ }^{6}$ Pokušavajući još jednom da odbrani tezu da prekarijat ima klasne karakteristike, za Standinga prekarijat se „sastoji od ljudi koji imaju minimalni odnos poverenja

\footnotetext{
${ }^{1}$ Tekst koji se nalazi pred čitaocima predstavlja pripremni deo analize rezultata koja ce da usledi u okviru autorkinog pisanja doktorske disertacije.

2 "Neoliberalni projekat zasnovan na kompeticiji i individualizmu, liberalizaciji svetske trgovine i masovnoj privatizaciji, te fleksibilizaciji tržišta radne snage, uz redukovanje i komercijalizaciju programa države blagostanja. Regresivna redistribucija u korist bogatih, i komodifikacija, tj. pretakanje u robni status svake aktivnosti, deo su projekta koji traži institucije koje favorizuju stvaranje prekarnih poslova i redukciju uloge države da bi se povećao nesmetani obrt kapitala" (Ružica, 2015: 31)

3 André Gorz je predviđao odumiranje radničke klase (Gorc, 1982).

${ }_{4}$ Cilj i obim rada ograničavaju mogućnost prikazivanja polemike i naučne debate da li je moguce govoriti o novom fenomenu ili je pak reč samo o savremenoj prekarnosti, koja se oduvek vezivala za kapitalizam, samo sada dobija nove oblike, no ti oblici suštinski ne menjaju osnovu društvene stratifikacije (v. Betti, 2016; Breman, 2013; Frase, 2013; Kalleberg, 2009; Wright, 2016).

5 Pripadnici poslednje grupe imaju znatno ograničeniji opseg prava od građana, svi oni koji ne uživaju neka od osnovnih građanskih prava: jednakost pred zakonom, pravo na zadovoljenje kulturnih, socijalnih (socijalna zaštita, penzije, zdravstvena nega), ekonomskih (pravo da naplate svoj rad), političkih (pravo glasa i učešce u političkom životu zajednice) potreba. Nepripadajući građani su „preklinjući“, mole za usluge i bilo kakve pogodnosti, a posebnu grupu nepripadajućih čine migranti, U ovoj kategoriji bi se našli, pored migranata, Romi, etničke manjine, osobe sa invaliditetom, bivši osuđenici.

6 „Guy Standing u svojoj knjizi teorijski razlikuje sledeće klase u savremenom britanskom društvu: vladajuća elita, salarijat, proficians (hibridna grupa koja spaja profesionalce i tehničare), manualni radnici starog proletarijata, prekarijat i lumpenproletarijat“ (Standing, prema Marković, Jovanović-Ajzenhamer: 539).
} 
prema kapitalu ili državi, čime se razlikuje od salarijata. Nema nijednog od društveno-ugovornih odnosa proletarijata s kojima je radna sigurnost bila pružena u zamenu za podređenost i kontingentnu lojalnost, što je bio nepisani ugovor u podlozi socijalne države. Bez pogodbe poverenja ili sigurnosti u razmenu za podređenost, prekarijat je distinktivan u klasnim terminima. Takođe ima osobitu statusnu poziciju po tome što se ne može uredno preslikati ni u zanimanja s visokim, ni u ona sa srednjim statusom. Može se reći da prekarijat ima ,okrnjen status'. (...) njegova struktura, društvenog dohotka' se ne može uredno preslikati ni u stare predstave o klasi, niti zanimanja“" (Standing prema Starčević, 2014: 49).7

No, da bi se o prekarijatu moglo govoriti u okvirima posebne društvene grupacije u konkretnom društvu, neophodno je najpre nešto reći i o samoj prirodi društvene strukture i sistema. Pripadnici prekarijata ne levitiraju nezavisno jedni od drugih i od ostalih društvenih grupacija, a da bismo mogli da pokušamo da proniknemo u osnovne karakteristike ove društvene grupacije, potrebno je pre svega reći nešto o samoj društvenoj strukturi i sistemu, te dosadašnjim naporima da se protumače (teorijski i empirijski) odnosi pojedinačnih elemenata koji čine jedan društveni sistem.

\section{OSNOVNA POLAZIŠTA O DRUŠTVENOJ STRUKTURI I DRUŠTVENIM NEJEDNAKOSTIMA}

Još od najranijih spisa o prirodi ljudskih društava prepoznato je da je u središtu društvene organizacije socijalna stratifikacija. Moglo bi se pristupiti hronološkom i istorijskom sagledavanju razlikovanja društvene strukture kod različitih mislilaca, no dovoljno je primetiti da gotovo da nema autora koji je promišljao društvo a da nije primetio podele $\mathrm{u}$ istom. Sam „pojam strukture pretpostavlja postojanje neke nehomogene i izdiferencirane celine, čija diferencijacija ima relativno stabilan oblik, tako da se u odnosima između delova i obeležja celine mogu utvrditi razne pravilnosti“"(Milić, 1996: 23).

Posmatrajući koren reči stratifikacija (od latinske reči strātum, strata (pl.) koja znači sloj, naslaga) razumljivo je da je reč o svojevrsnom rangiranju pojedinaca ili društvenih grupa u društvu. Nejednakosti u društvima se uzimaju bezmalo kao nešto univerzalno, ali pojam društvene stratifikacije ne podrazumeva samo nejednakosti, već pretpostavlja i „sistem sa prilično predvidljivim pravilima koja stoje iza rangiranja pojedinaca i grupa, a koje teorije društvene stratifikacije nastoje da otkriju i razumeju“ (Kerbo, 2007: 308). Da bi se obezbedilo relativno stabilno funkcionisanje takvog sistema, neophodna je i legitimacija istog, što je oličeno u

\footnotetext{
7 Dok pokušava da govori o klasnoj strukturi, Standing govori o poverenju (v. Standing, 2011: 8), koje je povezano sa legitimacijom, što su zapravo pojmovi sociologije politike i odnose se na politički podsistem, a ne na društvenu stratifikaciju. Drugim rečima, postavlja se pitanje da li je klasa za ovog autora pre politička nego ekonomska kategorija?
} 


\section{Zbornik IKSI, 2-3/2020 - A. Marković \\ „Prekarijat i neka pitanja društvene strukture i društvenih nejednakosti”, (str. 109-126)}

sistemu verovanja koji opravdavaju postojanje društvenih nejednakosti. ${ }^{8}$ Osnovne komponente stratifikacijskog sistema čine: 1) određivanje kriterija šta je to što $u$ jednom društvu važi za vrednost ili dobro koje je nejednako raspoređeno ${ }^{9}, 2$ ) pravila alokacije ovih resursa i 3) mehanizmi mobilnosti koji povezuju pojedince sa pozicijama na društvenoj lestvici koje generišu određeni nivo tih vrednih resursa. Ovome bi se moglo dodati i težnja svake društvene grupe koja pripada određenom stratumu da razvije vlastitu subkulturu.

Američki sociolog David Grusky sažeo je vredna dobra koja se u literaturi javljaju, a koja čine osnovu društvene stratifikacije. Tako razlikuje sledeće resurse: ekonomske, političke, kulturne, socijalne, prestiž (honorific), građanske (civil) i ljudske (human). U ekonomske resurse spadaju bogatstvo (wealth), prihodi (income) i vlasništvo (ownership) a predstavnici onih koji veruju da na ovim resursima počiva stratifikacija su Karl Marx i Erik O. Wright; u političke spadaju politička moć, autoritet na radnom mestu i autoritet u domaćinstvu sa predstavnicima poput Webera i Dahrendorfa; kulturni podrazumevaju znanje, digitalnu pismenost (digital culture) i „dobre“ manire, a tipični predstavnici su Pierre Bourdieu i Paul DiMaggio. Socijalni resursi su ono što Bourdieu naziva socijalnim kapitalom, a odnose se na pristup društvenim grupama koje su više na hijerarhijskoj lestvici stratifikacije (social clubs), ali i generalno neformalne mreže i kontakti, kao i sindikalno članstvo - predstavnici su W. Loyd Warner i James Coleman. Prestiž počiva na „dobroj reputaciji“, slavi, poštovanju, a može počivati na zanimanju, religijskoj pripadnosti ili nekoj zasluzi, a kao predstavnici navode se Edward Shils i Donald Treiman. Građanski resursi odnose se na pravo na privatno vlasništvo, pravo glasa, slobodu udruživanja i govora (Thomas Humphrey Marshall), dok ljudski resursi podrazumevaju veštine, stručnost, formalno obrazovanje, iskustvo (predstavnik je Gary Becker) (Grusky, 2001: 14444; Grusky, Ku, 2008: 5-6). ${ }^{10}$

Funkcionalistički pristup socijalnoj stratifikaciji, u skladu sa samom teorijom, pretpostavlja da stratifikacijski sistem doprinosi održavanju reda, stabilnosti i funkcionisanju samog društva. Talcott Parsons veruje da je stratifikacija usko povezana sa vrednosnim konsenzusom u društvu, odnosno da je zajednički sistem vrednosti taj koji određuje gde ce koji pojedinac biti pozicioniran u društvenoj hijerarhiji i da upravo ovaj zajednički sistem vrednosti legitimiše nejednaku raspodelu nagrada - on je neizbežan, ali i funkcionalan, jer obezbeđuje integraciju pojedinaca i društvenih grupa u društvo (Haralambos, Holborn, 2002: 48-49). Pored pojma društvene strukture, za funkcionalistički pristup od velikog su značaja i

\footnotetext{
${ }^{8}$ Naravno, društveni sistemi se ne integrišu isključivo preko sistema vrednosti, integracija se vrši i u političkoj, ekonomskoj, sociokulturnoj (pre svega kroz procese socijalizacije), zakonskoj sferi.

9 Na ovom mestu moglo bi se postaviti pitanje da li to znači da je stratifikacija predstava, a ne nešto što realno postoji? Tu bi valjalo istaći da je, kako primećuje Rudi Supek, stratifikacija „pozitivna činjenica“, ona je data objektivno, nju uočava svaki društveni teoretičar bez obzira na svoju teorijsku tačku od koje polazi. Sa druge strane, za Supeka, kako u metodološkom tako i u epistemološkom pogledu, nalaze se društvene klase, koje su i objektivne, ali i subjektivne, „djelomično „pozitivna činjenica“ a djelomično „dijalektička činjenica“““ (više u Supek, 1977b: 93).

${ }_{10}$ U radu sa Manwai C. Ku dodati su i psihološki resursi, koji predstavljaju smrtnost (neki ljudi žive duže neki kraće), fizičke i mentalne smetnje (Grusky, Ku, 2008: 6).
} 
pojmovi podele rada i društvene uloge. Društvena podela rada podrazumeva sve oblike društveno neophodne ljudske aktivnosti, razuđena je kako horizontalno tako i vertikalno ${ }^{11}$ (Milić, 1996: 24-28).

Najpoznatije funkcionalističko objašnjenje društvene slojevitosti jeste ono koje su Kinglsey Davis i Wilbert E. Moore ponudili još 1945. godine u članku „Neki principi stratifikacije“. Osnovna ideja od koje ovi autori polaze jeste funkcionalistička nužnost stratifikacije - društvena stratifikacija ne samo da postoji u svim poznatim društvima, već je ona i neophodna ukoliko društveni sistem želi opstati i funkcionisati. Osnovna funkcija stratifikacije jeste da poveže najsposobnije pojedince sa funkcionalno najznačajnijim položajima, što se postiže podsticanjem motivacije pojedinaca da se bore za najbolje položaje koji sa sobom nose i nagrade (prestiž, visoki prihodi, slobodno vreme i sl.). Društvena nejednakost se održava motivišući članove društva koji su talentovani da prođu nužno školovanje kako bi stekli veštine koje su potrebne za obavljanje važnih zadataka, ali ih takođe motiviše i kasnije u profesionalnom životu da ispune svoje obveze i obavljaju ih savesno (Davis, Moore, 1945).

Društvena slojevitost zasnovana je na individualnom i na slojnom položaju pojedinaca ili društvenih grupa. Društveni položaj je najtešnje povezan sa društvenom ulogom, no društveni sloj, kao realan društveni oblik a ne apstraktnoanalitička konstrukcija, ima tri osnovna obeležja: čine ga lica koja dele slične društvene položaje, on je okvir u kojem se dominantno odigravaju društveni odnosi pripadnika jednog sloja, odnosno pripadnici istog sloja dele sličan način života i sličnost u nizu kulturnih karakteristika. Izuzetno je važno primetiti da društveni slojevi u jednom društvu ne moraju biti raspoređeni u jedinstvenom vertikalnom nizu. Naprotiv, „društveni slojevi su vertikalno raspoređeni u društvenoj strukturi prema različitom stepenu posedovanja onih društvenih vrednosti koje su od odlučujućeg značaja za formiranje društvene slojevitosti“ (Milić, 1996: 41). Premda je prethodno izneto da društveni slojevi nisu u potpunosti homogeni, to ne znači da oni nisu relativno homogeni. Različiti tipovi međuslojnih odnosa najvidljiviji su ukoliko se sagledava borba oko slojnih interesa, dok se moralna integracija slojeva zasniva na njihovoj specifičnoj kulturi ${ }^{12}$ (Ibid: 30-50).

Niz nedostataka funkcionalističke teorije može se sažeti u kritiku: funkcionalne važnosti društvenih položaja, zanemarivanje uticaja moći na nejednaku raspodelu nagrada, dekonstrukciju pojma „talenta“ pojedinca, nejednakost mogućnosti,

\footnotetext{
${ }^{11}$ Horizontalna razuđenost ogleda se u pojmu društvene uloge, kojim se objašnjava povezivanje društvene aktivnosti pojedinca sa opštom podelom rada. Pojedinac može (i po pravilu ima) više (simultanih) društvenih uloga tokom svog života, a sukobi između uloga, koji nastaju kao posledica obaveza i normi različitih uloga, nisu neuobičajeni. Pojam društvene uloge povezan je i sa vertikalnom razuđenošću pojma podele rada. Naime, osnovne društvene uloge pojedinca su te koje određuju i njegov položaj u društvenoj strukturi (Milić, 1996).

12 Od posebne važnosti u izučavanju moralne integracije društvenog sloja javljaju se pitanja socijalizacije (posebno tzv. „anticipativne socijalizacije“), kao i političke integracije. No, čini se da Milić na ovom mestu funkcionalistički zapostavlja partikularne interese, u smislu potencijalnog pravca akcije.
} 
problem motivacije (v. Haralambos, Holborn, 2002: 50-52). Naime, funkcionalni značaj uloge mogućno je posmatrati kao značaj uloge za razvoj celog društva ili kao značaj za očuvanje konkretne društvene organizacije. Vladajući slojevi najčešće gledaju na određenu društvenu ulogu kao značajnu za održanje postojeće društvene strukture, te koriste svoju prevlast za precenjivanje vlasititih uloga i dodeljivanje nagrada koje taj položaj nosi, a sve sa ciljem kumulativnog jačanja sopstvenih društvenih pozicija. Drugim rečima, nijedan sistem raspodele društveno vrednih dobara i nagrada ne bi smeo da se apriori smatra adekvatnim izrazom društvenog značaja pojedinih uloga. Takođe, pogrešno bi bilo zaključiti da se materijalne nagrade raspodeljuju u skladu sa stvarnim sposobnostima nosilaca određenih društvenih uloga, jer neretko prilikom selekcije za određenu društvenu ulogu prioritet biva konformistički stav prema postojećem tipu društvene organizacije (Milić, 1996: 28-29).

Za razliku od funkcionalističkih teorija, koje ističu značaj i ulogu konsenzusa u društvu, konfliktne teorije polaze od toga da u društvu postoje nepomirljive razlike u interesima različitih društvenih grupacija, koje rađaju sukobe u društvu. Kada je reč o društvenoj stratifikaciji iz konfliktne perspektive, Hermann Strasser razlikuje tzv. konzervativni tip konflikte teorije (čiji su predstavnici, na primer, Max Weber i Ralf Dahrendorf) od tzv. progresivne konfliktne teorije (čiji su predstavnici, na primer, Karl Marx, Erik O. Wright ili Nicos Poulantzas). Dok je funkcionalistička teorija društvene stratifikacije predstavljala strategiju za rešavanje problema motivacije (koji leži u potrebi industrijskog društva da osigura adekvatnu kvalifikaciju i učinak), konzervativna konfliktna teorija predstavlja strategiju za rešavanje problema društvene kontrole, kao posledice imperativa društva birokratske organizacije, odnosno progresivna teorija sukoba predstavlja strategiju za eliminaciju asimetričnih odnosa razmene, koji proizlaze iz kapitalističkog imperativa proizvodnje, tržišnog takmičenja i maksimizacije profita, što vodi ka alijenaciji i eksploataciji. U okviru opšte teorije društvene strukture navedene funkcionalistička teorija i konzervativna/progresivna teorija sukoba se razlikuju u pogledu normativne perspektive i usmeravanja istraživačkog interesovanja (funkcionalistička i konzervativna konfliktna teorija počivaju na konzervativnoj socijalno-tehnološkoj, dok progresivno konfliktna teorija počiva na progresivnoj, socijalnoemancipatorskoj perspektivi), vokabularu društvenog objašnjenja stratifikacije (prva počiva na redu, druge dve na sukobu), problematizovanom aspektu društvenog poretka (kod funkcionalističke perspektive to je društvena organizacija i njena sinhronijsko-homeostatska dimenzija, kod konzervativno konfliktne je to društveni razvoj i dijahronijska i dimenzija geneze, dok je kod progresivne konfliktne teorije to društvena razmena i autonomna dimenzija).$^{13} \mathrm{U}$ pogledu kolektivnih, društvenih problema, grupisanja i nejednakosti predstavljene perspektive razlikuju se u pogledu: rešavanja društvenih problema (socijalizacija je rešenje prve, društvena

\footnotetext{
${ }^{13}$ Strasser ovde izostavlja to da je još Merton u svojoj „paradigmi za funkcionalnu analizu u u sociologiji“ (v. Merton, 1998) uvođenjem pojma disfunkcije otvorio put ka konfliktizaciji i uvođenju dinamike u klasičan (Parsonsov) funkcionalizam, te činjenicu da neofunkcionalizam još od Jeffrey C. Alexandera ima diferenciran stav prema konfliktima (v. Alexander, 1985).
} 
kontrola druge, a nužnost prirodnog toka (mastery of nature) treće perspektive), grupa i institucija koje rešavaju probleme (porodica/škola/crkva/vršnjačke grupe/sredstva masovnog opštenja vs. političke partije/država/lideri vs. profesionalne i ekonomske skupine), slojeva koji reprezentuju društvene jednakosti (statusne grupe; elite i ne-elite; klase). Spram normativnih i konceptualnih kategorija ove grupe teorija razlikuju se po centralnom konceptualnom pojmu (profesionalna struktura odnosno struktura prema zanimanjima; struktura vlasti i autoriteta; klasna struktura) ali i po idealu društvene pravde (kod funkcionalizma i konzervativne konfliktne teorije to je meritokratski ideal jednakosti šansi, dok je kod progresivnih konfliktnih teorija to egalitarni ideal distributivne pravde). Dok funkcionalistička perspektiva počiva na nominalističkom viđenju slojne strukture društva, obe konflikte teorije počivaju na realizmu klasne strukture; dok identitet počiva na sličnosti u funkcionalizmu, dotle u konfliktnim teorijama on počiva na sukobu; dok je osnovna ljudska potreba za funkcionaliste saradnja i zajednički identitet (princip homogenosti), njihovi oponenti smatraju da je to princip heterogenosti (samoočuvanje i samoaktuelizacija). Najzad, ljudska aktivnost i društvena akcija se ispoljavaju u svom materijalnom obliku putem interakcije za funkcionaliste, odnosno kroz rad i tržište rada za konflikte teorije; povezujući element je za prve status, a za druge moć; funkcionalisti su orijentisani na društvenu reprodukciju a njihovi oponenti na društvenu produkciju tj. društvenu proizvodnju (Strasser, 1980: 105-109). Kao (istorijski i konceptualno) najpoznatiji oblici društvene slojevitosti javljaju se kasta, stalež i klasa (Milić, 1996: 50-51). Klasični funkcionalisti neće se baviti istorijskim oblicima slojevitosti, nego ce upotrebiti pojam sloj.

U ovom pojmovnom razlikovanju valja se vratiti na Webera. U skladu sa analitičkom trijadom razlikujemo klase, staleže i partije, međutim, one su samo na idealnotipskom nivou međusobno odvojene; u empirijskoj realnosti te grupacije ponekad zajedno delaju, no ipak je u najvećem broju slučajeva njihovo društveno delanje poprilično difuzno (Đurić, 1964: 143; Saunders, 1990: 20). Weber klasni položaj vezuje za položaj na tržištu rada, a statusni položaj za društveni ugled koji je određen načinom života pojedinca (pri čemu iz socijalnog isključuje tržište, odnosno ekonomiju uopšte). Bogatstvo i stručnost, koji jesu pokazatelji klasnog položaja, nisu pokazatelji i statusnog položaja određenog u ovom smislu. Pokazatelj statusnog položaja je društveni ugled. Pri tom postoji tešnja veza između stručnosti (najčešće operacionalizovane preko formalnog obrazovanja) i ugleda, nego što je slučaj sa bogatstvom. Međutim, kada govorimo o savremenom društvu (,vremenu prekarijata“), moglo bi se govoriti i čak o pojačanoj vezi između bogatstva i ugleda. Naime, u vremenima kada postoji sve više tehničkih, rutinskih poslova i kada neretko pojedinci rade na poslovima koji su ispod njihovog nivoa kvalifikacija (poslove za koje su „prekvalifikovani“), ugled se pre može vezati za bogatstvo nego za stručnost.

Iz navedenog već se vidi da su za Webera staleške grupe sinonim za statusne grupe. Za razliku od marksističkog stajališta koje klasama daje delatni potencijal, Weberove 
klase ${ }^{14}$ se od staleža razlikuju i po nedostatku samosvesti i delatnog potencijala, dok Marks upravo ovako određuje društveni sloj, za razliku od klase. ${ }^{15}$ „Najvažniji raskid koji je Weber napravio sa Marxom tiče se istorijske determinacije razvoja klasne svesti. Weber poprilično decidirano ističe da kolektivno klasno delanje uopšte ne mora da bude karakteristika društvene realnosti, naprotiv, ona to najčešce i nije. (...) Za razliku od Marxovog viđenja, za Webera osnovna protivurečnost modernog kapitalizma nije između rada i kapitala ${ }^{16}$, nego između produktivnih i neproduktivnih načina sticanja“ (Marković, Jovanović-Ajzenhamer, 2018: 536). ${ }^{17}$ Najzad, treća strukturalna grupacija u stratifikacijskoj shemi jesu stranke, koje određuju institucionalni položaj pojedinca. Osnov grupisanja u ovom slučaju je interes, a moć koja se vezuje za ovu grupu jeste politička moć (za klase bi to bila ekonomska, a za staleže socijalna moć). Stanje privrede u jednom društvu je to koje određuje koja će od ove tri strukturalne grupacije odnosno podele preovladavati (Antonić, 2009; Wright, 2015). ${ }^{18}$

Mihailo Popović govori o tri pristupa razlikovanja klasa i slojeva: prvi bi podrazumevao da su slojevi samo deo klase, te da u okviru jedne klase možemo razlikovati više slojeva ${ }^{19}$, bilo kao realnu socijalnu grupu bilo kao samo socijalnostatističku konstrukciju; drugi pristup suprotstavlja klasu i sloj, gde prvu vidi kao analitičku i kategoriju ekonomske moći a drugu kao deskriptivnu i kategoriju društvenog ugleda, društveni položaj prvih počiva na svojini sredstava za proizvodnju a društveni položaj drugih na mestu u društvenoj podeli rada odnosno na profesionalnoj ulozi; dok se treći pristup oslanja na slojevitost kao takvu, te u okviru nje, klase vidi samo kao jedan od različitih oblika društvene slojevitosti (v. Popović, 1994: 79-96). Prema Popoviću, „proizilazi prilično jasno da su slojevi društvene grupacije koje se formiraju po nekom hijerarhijskom redosledu, da se razvrstavaju po vertikalnoj dimenziji „društvenog prostora“, dok su klase grupacije koje se nalaze jedna nasuprot drugoj, koje pripadaju više horizontalnoj dimenziji

\footnotetext{
${ }_{14}$ "Interesantno je da je Weberova teorija o klasama i staležima tavorila na marginama svetske sociologije sve do pedesetih godina prošlog veka (...) kada je napokon objavljen skup Weberovih tekstova koji se tiču društvene stratifikacije počela je inflacija naučnih studija koje možemo nazvati neoveberijanskim pristupom analizi klasa" (Marković, Jovanović-Ajzenhamer, 2018: 535).

${ }_{15}$ "Ukoliko milioni porodica žive pod ekonomskim uslovima egzistencije koji njihov način života, njihove interese i njihovo obrazovanje odvajaju od načina života, interesa i obrazovanja drugih klasa i njima ih ne prijateljski suprotstavljaju, utoliko oni čine klasu. Ukoliko među parcelnim seljacima postoji samo lokalna povezanost, ukoliko istovetnost njihovih interesa ne stvara zajednicu, ne stvara nacionalnu vezu i političku organizaciju među njima, utoliko oni ne čine klasu“ (Marks, 2011:106). 16 "Ali naša epoha, epoha buržoazije, odlikuje se time što je uprostila klasne suprotnosti. Celo se društvo sve više i više cepa na dva velika neprijateljska tabora, na dve velike klase koje stoje neposredno jedna naspram druge - buržoaziju i proletarijat" (Marks, Engels, 1945: 32)

${ }_{17}$ "Svaka klasa može da bude nosilac nekog od bezbrojnih mogućih oblika 'klasnog delanja', ali ona to ne mora biti; u svakom slučaju ona sama nije zajednica” (Veber, 1976: 34).

${ }_{18}$ Više o genezi nastanka koncepta prekarijata kroz prizmu Maxa Webera u Marković, JovanovićAjzenhamer, 2018.

19 Tako Mladen Lazić, govoreći o klasnoj analizi (najpre jugoslovenskog, kasnije srpskog društva) kaže da „u istorijski datom društvenom sistemu egzistira više klasa, a one same podeljene su na veći broj podgrupa (slojeva)“ (Lazić prema Cvejić, 2006: 8).
} 


\section{Zbornik IKSI, 2-3/2020 - A. Marković \\ „Prekarijat i neka pitanja društvene strukture i društvenih nejednakosti”, (str. 109-126)}

ovog prostora ${ }^{20}$. Slojevi su kontinuirane grupe koje raspolažu sa više ili manje nekom osobinom, koja je uzeta kao osnova hijerarhijskog razvrstavanja (više ili manje prihoda, više ili niže obrazovanje, veći ili manji ugled). Klase su, naprotiv, diskretne društvene grupe, koje se međusobno razlikuju po tome da li imaju nešto uopšte ili nemaju, bar kada su u pitanju osnovne klase (ima sredstava za proizvodnju, nema ova sredstva)“ (Popović, 1994: 88).

Priroda društvene strukture, hijerarhijski poredak, odnosi između društvenih grupacija, socijalna distanca i percepcija vlastitog položaja, kao i osnovni kriterijumi na osnovu kojih društveni teoretičari pokušavaju da izvedu svoje teorije društvene strukture i sistema, podelilo je sociologe u sagledavanju društvene realnosti. Do sada je akcenat bio na funkcionalističkim pristupima, uz komentare i kritike upućene iz konfliktne perspektive. O Marxu kao glavnom predstavniku konfliktnih teorija suvislo je za potrebe ovog rada iznositi detaljno njegovu čitavu teorijsku koncepciju, a čitaoci su svakako upoznati sa osnovnim pojmovima marksizma. No Marx kao osnovni kriterijum za određivanje klasa uzima odnose u proizvodnji, način sticanja dohotka i način raspodele dohotka. U osnovi klasne podele svakako stoji zakon podele rada, jer klase i nastaju i razvijaju se zajedno sa razvojem materijalnih proizvodnih snaga i radne produktivnosti. „Između klasa i načina proizvodnje postoji dijalektička interakcija. Klase su nosilac načina proizvodnje i obratno, u osnovi formiranja klasa djeluje zakonitost načina proizvodnje“ (Supek, 1977a: 100). Način sticanja dohotka za Marxa nije dovoljan za objašnjenje koji to elementi sačinjavaju osnovne klase u društvu, stoga se on okreće i načinu raspodele dohotka. $\mathrm{Na}$ ovaj način prevazilazi funkcionalistički, kvantitativni kriterijum u teoriji socijalne stratifikacije, gde je visina dohotka merilo za položaj pojedinca na društvenoj lestvici. Naime, najamnina, profit i renta su ti koji su kvalitativni kriterijum za određivanje mesta klase (podvukla A.M.) u načinu raspodele dohodaka. (Ibid: 101). Prema Supeku, Leninova (Vladimir Ilyich Lenin) definicija klasa ${ }^{21}$ korisna je dopuna Marxovog određenja jer „se može korisno upotrebiti za izučavanje svih promjena koje su nastale na nivou ekonomskih ili proizvodnih odnosa u toku razvitka samog kapitalizma" (Supek, 1977b: 96), a posebno u pogledu dominacije i subordinacije tj. hijerarhije moći, tendenciji razvitka „privatnih u kolektivna“ vlasništva i javljanje akcionarskih društava, korporacija i sl., „menadžerskoj revoluciji“ i neutralizaciji

\footnotetext{
${ }^{20}$ Sam Popović ipak (u donekle pesimističnom tonu) priznaje da navedene horizontalna i vertikalna dimenzija posmatranja nisu isključive za klasu odnosno sloj. „Mada ima, dakle, razloga da se društveni slojevi shvate pre svega kao vertikalne, hijerarhijske grupacije, a klase kao horizontalne, suprotstavljene grupe, ostaje činjenica da i klase imaju svoju vertikalnu dimenziju. I to ne samo iz razloga što se i klase nalaze jedna „iznad“ druge usled nejednake raspodele društvene moći, nego i zato što i slojevi mogu da dođu u međusobni konflikt, ako se „sudare“ njihovi različiti interesi. Sve to pokazuje da naša sociološka imaginacija (...) ne može do kraja da predstavi i razjasni bitne sociološke razlike između društvenih klasa i društvenih slojeva, ako uopšte takve razlike između njih postoje (Popović, 1994: 89-90).

${ }^{21}$ „Klase se zovu velike grupe ljudi koje se razlikuju po svome mestu u istorijski određenom sistemu društvene proizvodnje, po svome odnosu (većinom utvrđenom i izraženom u zakonima) prema sredstvima za proizvodnju, po svojoj ulozi u društvenoj organizaciji rada i, prema tome, po načinu stjecanja i po veličini onog dela društvenog bogatstva kojim raspolažu. Klase su takve grupe ljudi od kojih jedna može da prisvaja rad druge zahvaljujući tome što imaju različita mesta u određenom sistemu društvene privrede“ (Lenin, prema Supek, 1977b: 97-98).
} 


\author{
Zbornik IKSI, 2-3/202O - A. Marković \\ „Prekarijat i neka pitanja društvene strukture i društvenih nejednakosti”, (str. 109-126)
}

klasnog pitanja zamenom teza o tehnokratiji, te u pogledu „viška rada i njegove distribucije“22 (Ibid: 96-97).

Obim ovog rada ne dozvoljava prikaz konkretnih empirijskih istraživanja društvene strukture kako u domaćoj tako i u stranoj sociologiji tokom decenija unazad (v. Cvejić, 2006; Evans, 1992; Evans, Mills, 1998; Evans, Mills, 2000; Goldthorpe, Hope, 1972; Goldthorpe, 1980; Haralambos, Holborn, 2002; Lazić, 1987; Lazić, 2011; Lazić, Cvejić, 2019; Marshall et al, 1988; Milić, 1996; Popović, 1994; Rose, O'Reilly, 1997; Savage et al, 2013; Supek, 1961; Warner et al, 1949; Wright, 1988; Wright, 2005; Wright, 2015 itd.). Istraživanje i interesovanje za društvenu slojevitost $\mathrm{u}$ američkoj sociologiji došlo je znatno kasnije nego u evropskoj. ${ }^{23}$ Stoga u nastavku ovog rada sledi prikaz i kritika jednog od, za sada, najuticajnijih empirijskih istraživanja društvene strukture u kojem je prekarijat prepoznat kao jedna od društvenih grupa koji sačinjavaju strukturu britanskog društva.

\title{
2. PREKARIJAT KAO KLASA (U NASTAJANJU?) - EMPIRIJSKO ISTRAŽIVANJE U VELIKOJ BRITANIJI
}

Veliko empirijsko istraživanje društvenih klasa u Velikoj Britaniji (BBC's Great British Class Survey) iz 2011. godine jasan je pokazatelj da je Standingov pojam imao odjeka u sociološkim istraživanjima društvene stratifikacije, koje je uz saradnike izneo britanski sociolog Mike Savage (Savage et al, 2013). ${ }^{24}$ Savage je sa svojim saradnicima zapravo pokušao da proširi Goldthorpeovu klasnu shemu (Goldthorpe class schema) Bourdieuovim konceptima kapitala ${ }^{25}$, ističući da klasna shema zasnovana na zanimanju ne beleži dobro sve društvene i kulturne procese $u$ nastajanju klasa. Posebno se oslanjajući na Bourdieuov pojam ekonomskog, socijalnog (koji se meri mrežom i prirodom društvenih kontakata) i kulturnog kapitala, kojim dopunjuju svoju operacionalizaciju i teorijsku postavku istraživanja klasne strukture britanskog društva, autori uvode dve podvrste kulturnog kapitala. Razlikovali su "prefinjeni” (highbrow) kulturni kapital, koji je instrumentalizovan kroz pitanja o konzumiranju klasične muzikom, posete muzeja, umetničkih galerija, džeza, pozorišta i francuskih restorana. Maksimalna ocena koju bi ispitanik mogao dobiti (ako se „često“ bavi svim ovim aktivnostima) je 30. Druga ocena odnosi se na

\footnotetext{
${ }^{22}$ Supek ovde misli pre svega na „problem birokratije u socijalizmu koja raspolaže tužim viškom rada“" (Supek, 1977b: 97).

23 Zapravo, istraživanja društvene stratifikacije u Americi bila su podstaknuta tek Velikom depresijom 1929. godine.

${ }_{24}$ Nije retko da društveni teoretičari menjaju svoja stanovišta tokom decenija rada i istraživanja. Kako Savage sam priznaje, njegov rad i intelektualna trajektorija kretali su se od interesovanja za radničku klasu, preko posebnog zanimanja za srednju klasu, pa do fokusa na celokupnu društvenu strukturu u poslednjim radovima (Savage, 2016). Rani radovi ovog autora i saradnika bili su u korenu marksistički što je vidljivo u posmatranju klase kao grupa ukorenjenih u posebnim tipovima odnosa eksploatacije. Ipak, udaljavanje od čisto marksističke pozicije je jasno vidljivo. Poseban značaj u oblikovanju klasa pridaje se životnim stilovima, a klasama (za razliku od Weber-a) Savage i saradnici ipak daju mogućnost kolektivnog delanja, posebno u kontekstu promena koje ce uticati na razvoj društva.

${ }^{25}$ Koji razlikuje ekonomski, kulturni, socijalni i simbolički kapital (v. Nemanjić, Spasić, 2006)
} 


\section{Zbormik IKSI, 2-3/2020 - A. Marković \\ „Prekarijat i neka pitanja društvene strukture i društvenih nejednakosti”, (str. 109-126)}

„novi“ kulturni kapital u nastajanju (emerging cultural capital), koji se zasniva na opsegu angažovanja i konzumacije moderne tehnologije, video igre, društvenoj mreže i sajtove, bavljenje sportom, gledanje sporta, druženje sa prijateljima, odlazak u teretanu, odlazak na popularne koncerte i preferencije za rep i rok muziku. Maksimalna ocena koju bi ispitanik mogao dobiti (ako se „često“ bavi svim ovim aktivnostima) je 32 (Savage et al, 2013: 227).

Ovakvim pristupom, došli su do sedam klasnih kategorija: elita, tehnička srednja klasa, novi dobrostojeći radnici, tradicionalna radnička klasa, klasa uslužnih radnika u nastajanju i prekarijat. Tabela 1. daje osnovni prikaz društvenog strukturisanja, a kriterijum za svrstavanje pojedinaca biva posedovanje različite količine merenih kapitala. Autori su detaljno izložili i koja vrsta zanimanja je prezastupljena u kojoj klasi, geografsku raspodelu klasa itd, no na ovom mestu dovoljno je osvrnuti se samo na osnovne nalaze (Savage et al, 2013: 233-243). ${ }^{26}$

Tabela 1. Klasna struktura britanskog društva

\begin{tabular}{|c|c|c|c|}
\hline & $\begin{array}{l}\text { \% online } \\
\text { istraživanje }\end{array}$ & $\begin{array}{l}\text { \% terensko } \\
\text { istraživanje }\end{array}$ & Opis (posedovanje različitih vrsta kapitala) \\
\hline Elita & 6 & 22 & $\begin{array}{l}\text { Veoma visok nivo ekonomskog kapitala (posebno ušteđevine), visok } \\
\text { nivo socijalnog kapitala, vrlo visok nivo „kulturnog kapitala u } \\
\text { nastajanju“ }\end{array}$ \\
\hline $\begin{array}{l}\text { Etablirana srednja } \\
\text { klasa }\end{array}$ & 25 & 43 & $\begin{array}{l}\text { Visok nivo ekonomskog kapitala, visok nivo obe vrste kulturnog } \\
\text { kapitala, sa jakim (uglednim) socijalnim kontaktima }\end{array}$ \\
\hline $\begin{array}{l}\text { Tehnička srednja } \\
\text { klasa }\end{array}$ & 6 & 10 & $\begin{array}{l}\text { Visok nivo ekonomskog kapitala, relativno nizak socijalni kapital, ali sa } \\
\text { uglednim socijalnim kontaktima, umeren kulturni kapital }\end{array}$ \\
\hline $\begin{array}{l}\text { Novi dobrostojeći } \\
\text { radnici }\end{array}$ & 15 & 6 & $\begin{array}{l}\text { Umereno visok ekonomski kapital, umereno loš srednji skor socijalnih } \\
\text { kontakata (socijalnog kapitala), mada visok opseg, umereno visok nivo } \\
\text { „prefinjenog“ kulturnog kapitala, ali dobar skor u pogledu „kulturnog } \\
\text { kapital u nastajanju“ }\end{array}$ \\
\hline $\begin{array}{l}\text { Tradicionalna } \\
\text { radnička klasa }\end{array}$ & 14 & 2 & $\begin{array}{l}\text { Umereno nizak nivo ekonomskog kapitala (ali sa „pristojnom“ } \\
\text { (reasonable) cenom nekretnina u kojoj stanuju), malo socijalnih } \\
\text { kontakata, nizak nivo obe vrste kulturnog kapitala }\end{array}$ \\
\hline $\begin{array}{l}\text { Klasa uslužnih } \\
\text { radnika u nastajanju }\end{array}$ & 19 & 17 & 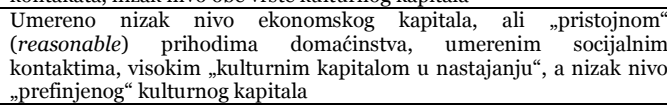 \\
\hline Prekarijat & 15 & $<1$ & $\begin{array}{l}\text { Veoma nizak (poor) ekonomski kapital i najniži rezultati po svim } \\
\text { ostalim kriterijumima }\end{array}$ \\
\hline
\end{tabular}

Savage et al. zaključuju da njihova višedimenzionalna analiza otkriva polarizaciju socijalne nejednakosti (u obliku elite i prekarijata), kao i fragmentaciju tradicionalnih socioloških podela srednje i radničke klase na više segmentirane oblike, te da su samo dve od sedam klasa u skladu su sa starijim sociološkim modelima „srednje“ i „radničke“ klase, što može biti indikator “zamagljenosti” i fragmentacije konvencionalnih granica „srednje“ i „radničke“ klase. Tradicionalna radnička klasa sve više bledi i iščezava u savremenom britanskom društvu i očito je manje istaknuta od etablirane srednje klase. Ukupno 39\% populacije ovi autori vide

${ }^{26} \mathrm{U}$ periodu od januara do jula 2011. godine prikupljeno 161.400 anketa. Međutim, ubrzo je postalo jasno da je anketa pretrpela snažnu pristrasnost selekcije, pri čemu su ispitanici pretežno bili iz dobro obrazovanih socijalnih grupa i "tipična BBC-jeva publika”. Stoga je sprovedeno i terensko istraživanje tehnikom face to face sa identičnim pitanjima, na uzorku od 1026 ispitanika. Meren je ekonomski, socijalni i kulturni kapital ispitanika a u analizi je korišćena latentna analiza klasa (Latent Class Analysis). Rezultati dati u Tabeli 1. pokazuju nalaze i iz online i iz terenskog „lice u lice“ istraživanja. 


\section{Zbornik IKSI, 2-3/2020 - A. Marković \\ „Prekarijat i neka pitanja društvene strukture i društvenih nejednakosti”, (str. 109-126)}

kao deo starih stratifikacijskih modela, dok većina populacije spada u klase koje nisu registrovane konvencionalnim pristupima $\mathrm{i}$ zahtevaju fluidnije razumevanje prekrajanja društvenih i kulturnih granica. Zbog toga u pojedinim klasama postoji prekomerna zastupljenost i tradicionalno belih i plavih okovratnika. Generalno, smatraju Savage et al, linija „okovratnika“ (plavih i belih, A.M.) je u savremenom britanskom društvu od male vrednosti u razotkrivanju novih obrazaca društvenog strukturiranja. Kao posebno zanimljive vide „klasu novih dobrostojećih radnika i klasu uslužnih radnika u nastajanju i smatraju da su ove dve klase u mnogočemu „deca“ tradicionalne radničke klase, pa bi se, prema tome, moglo reći da predstavljaju primer velikog prekida u kulturi radničke klase koji je bio očigledan kao posledica deindustrijalizacije, masovne nezaposlenosti, imigracija i restrukturiranja urbanog prostora. „Autori zaključuju da je došlo vreme za promene i da je pogrešno pokušavati da klase povežemo sa „blokovima zanimanja”, već da je sazrela jedna nova multidimenzionalna perspektiva, u kojoj se „pripadnost klasi na osnovu zanimanja“" prostire sada (i to neravnomerno) među različitim klasama“ (Marković, Jovanović-Ajzenhamer: 540; Savage et al.: 243-246).

Sociološkinja sa Bristolskog univerziteta Harriet Bradley kritikuje predstavljeno istraživanje u tri osnovne crte: 1) Pristup klasama je pre svega gradacijski i hijerarhijski, ali nije i relacioni. „Savage et al. grupišu ljude u klastere (oblake u društvenom prostoru) na osnovu njihovog posedovanja (ili ne) različitih označitelja tri oblika kapitala. To je, dakle, kategorijski ili gradacijski, a ne relacioni pristup klasama: klase nisu definisane prirodom međusobnih ekonomskih veza, već su postavljene na skali u smislu posedovanja manje ili više različitih sredstava. (...) Tvrdim da istinski sociološka teorija klase to shvata kao društveni odnos, a ne kao atribut ili skup atributa" (Bradley, 2014: 431); 2) Oznake kulturnog kapitala su visoko selektivne i stoga neprikladne za empirijsko operacionalizovanje - Bradley priznaje da postoji beskonačan niz kulturnih oblika i predmeta u društvima, a da su Savage i saradnici odabrali one koje su smatrali najvažnijima. No, smatra ova autorka, odabir je "staromodan" i podseća na stare rasprave o "visokoj" nasuprot "popularnoj" kulturi. Istraživači su srednju klasu identifikovali kao omnivore, ali u pogledu radničke klase postoji ambivalentnost: da li su oni samo jednostrani konzumenti (one-sided consumers) popularne kulture ili ih zapravo obeležava upravo nedostatak kulturne potrošnje? Autorka zamera dodatno što istraživači ne koriste "prepoznatljivu prirodu kulturnog života radničke klase": kladionice, pabovi, pikado, izleti na more, veštine „uradi sam“, profesionalno igranje fudbala, čitanje sportskih novina (iako Savage i saradnike "optužuje" za staromodan odabir kulturnih dobara?). 3) Kritika latentne klasne analize - klasa postaje merilo preko kojeg se pojedinci pozicioniraju u pogledu posedovanja manje ili više elemenata tri vrste kapitala. Klase se sastoje od pojedinaca grupisanih u smislu društvenih kontakata i kulturnih aktivnosti, ali ljudi iz istih zanimanja pojavljuju se u različitim klasama: negovatelji se tako pojavljuju u tri od njih. Gledajući zanimanja koja preovlađuju u svakoj identifikovanoj klasi, postavlja se pitanje da li postoji nešto što bi ih zaista spojilo u koherentno telo. „Odnos između klasa je tada gradacijski, a 
tačke preseka između klasa su relativno proizvoljne. Ovo zapravo priznaju i Savage i saradnici koji navode da oni ne „razvijaju deduktivnu shemu klasa“ (Savage et al, 2013: 229), već koriste različite indikatore za razlikovanje „parsimonistički“ ${ }^{27}$ statističkih grupa ljudi i odatle lociraju granice glavne klase. Ovo je njihova metoda „latentne analize klasa““ (Bradley, 2014: 433).

Ovim opravdanim kritikama moglo bi se dodati i to da insistiranje na pripadnosti klasi na osnovu zanimanja dodatno odvraća pažnju od svojinskog odnosa. Dok se izdvajaju dobrostojeći radnici, elita se mistifikuje, ne vidi se čiji materijalni položaj se zasniva na posedovanju zemlje (posebno u Velikoj Britaniji), na akcijama, ili pak drugim vrstama ekonomskog kapitala. Pritom, iako se oslanjaju na Standinga, koji jasno ističe da je podgrupa prekarijata tzv. kreativni prekarijat, a to su visokoobrazovani, Savage i saradnici isključuju visokoobrazovane iz grupe prekarijata, odnosno ono što bi za Standinga bio prekarijat (šesta i sedma klasa u Savage et al. istraživanju), kod ovih istraživača se opseg smanjuje, ali ne i toliko da zapravo ne pominju nigde pojedince koji se u ustaljenoj (marksističkoj) terminologiji javljaju kao potklasa ili lumpenproletarijat.

Bradley se ne zaustavlja samo na kritici Savage et al, već nudi i alternativnu klasnu shemu, za koju sama kaže da je mešavina marksističkog i veberijanskog pristupa. Naime, ona predlaže razlikovanje tri osnovne klase, s tim što, eventualno, dopušta razmišljanje i o postojanju četvrte (prekarijatu). Tri osnovne klase su: elita, srednja klasa i radnička klasa, svaka sa svojim frakcijama, s tim što je radnička klasa ta koja je u doba neoliberalizma doživela najveću transformaciju te i broji najviše frakcija (između ostalog i prekarijat, koji, eventualno, može biti posmatran kao zasebna klasa). Položaj na tržištu rada jeste bitna osnova za klasifikaciju klasa, ali pre svega ova autorka ističe ekonomsku dimenziju kao osnov grupisanja.

Elitu određuje prevashodno posedovanjem ekonomskog kapitala odnosno bogatstva (u smislu zemlje, imovine, akcija i ulaganja (investments), vlasništva $\mathrm{u}$ kompanijama), bez obzira što ovi pojedinci mogu ostvarivati i visok dohodak u vidu plata (kao na primer političari). Jednu frakciju unutar elite čine oni sa ekstremno visokim primanjima i bogatstvom, dok drugi deo frakcije čine "superbogati" (superrich), koji predstavljaju $0,01 \%$ svetskog stanovništva i to su pokretači globalnog neoliberalnog kapitala. Oni su globalna klasa, imaju bogatstvo, imovinu i investicije sa sedištem u velikom broju zemalja i međunarodno su mobilni. Za razliku od elite, srednju klasu, iako i oni mogu posedovati bogatstvo (u vidu nekretnina i akcija), pre svega određuje njihov dohodovni prihod. Oni su „zarađivači“ na visokom nivou, zarađuju na osnovu kvalifikacija, veština i odgovarajuće vrednovanog iskustva. Najpovoljnija frakcija srednje klase su "tradicionalni profesionalci" (lekari, advokati, inženjeri) i menadžerska elita (odnosno Goldthorpeova uslužna klasa). U nešto lošijem položaju u okviru srednje klase nalaze se pripadnici niže srednje klase, koju čine kvalifikovane, ali slabije plaćene profesije, poput medicinskih sestara, savetnika (council workers) i tehničara. Takođe, moguće je identifikovati i srednju-srednju

${ }^{27}$ Princip parsimonije kaže da od dve teorije o tome kako nešto funkcioniše po svoj prilici je tačnija ona koja je jednostavnija. 


\section{Zbornik IKSI, 2-3/2020 - A. Marković \\ „Prekarijat i neka pitanja društvene strukture i društvenih nejednakosti”, (str. 109-126)}

klasu visokoobrazovanih, manje nagrađivanih zanimanja: nastavnici, socijalni radnici i IT stručnjaci. Konačno, Bradley definiše u marksističkom tonu i radničku klasu, kao onu koja nema šta da proda osim svoje radne snage, sastavljenu od pojedinaca koji su slabo plaćeni, bez visokoobrazovanih kvalifikacija. Nju čine različite frakcije: relativno imućna (affluent) i ambiciozna gornja radnička klasa (kvalifikovani fizički radnici i rastući redovi tzv. white van men (tehnološki višak iz industrije i fabrika i "mehaničari" koji su svoje veštine iskoristili za samozapošljavanje)); feminizirana srednja frakcija radničke klase, slabo plaćenih radnika (pre svega radnica) u maloprodaji, nezi i uslugama „za slobodno vreme“ (leisure services); te frakcija koja zavisi od socijalnih primanja i naknada (uključujući i nezaposlene). Na ovom mestu, Bradley dopušta eventualno konceptualizaciju i prekarijata kao zasebne klase, odnosno heterogene grupacije koju čine i visokoobrazovane kao i vrlo niskokvalifikovani (čime direktno osporava stav Savage et al. da se prekarijat odlikuje nedostatkom svih vrsta kapitala). Prekarijat bi u tom slučaju sačinjavao armiju radnika na privremenim-povremenim poslovima, spremačice, asistente $u$ učionicama i predavače koji su plaćeni po satu, radnike $u$ call-centrima, berače voća, osoblje barova i restorana. "Prekarijat je definisan marginalnim i nesigurnim odnosom prema zaposlenju, u i izvan različitih vrsta privremenog i nepunog radnog vremena i loših ugovora; njegovi redovi sadrže mlade ljude, uključujući studente i „diplomce bez zaposlenja“, radnike migrante, radnike manjinskih etničkih grupa, žene i muškarce koji su nedavno postali tehnološki višak" (Bradley, 2014: 434-435). Sama po sebi ovo nije nova klasa, ali je njen nastanak i razvoj nov, uz dodatak kvalifikovanih i dobro obrazovanih radnika koji pate od politike štednje i globalnog neoliberalizma (Ibid: 433-435). Interesantno je da Bradley zapravo govori o prekarijatu kao o Standingovom prekarijatu i "klasi u nastajanju", a da se nijednom u svom članku ne poziva na Standinga niti ga navodi u spisku korišćene literature.

\section{UMESTO ZAKLJUČKA}

U prethodno iznetim redovima čitaocima je dat (kratki i svakako nedovoljni za sveobuhvatniju sliku) prikaz složenosti ispitivanja društvene strukture i sistema, pre svega kroz pregled osnovnih teorijskih pravaca proučavanja društvene stratifikacije i nejednakosti. Ukoliko na ionako kompleksan društveni fenomen dodamo i pitanje jednog sociološkog i teorijskog novuma - prekarijata, bilo da ga posmatramo kao potpuno nov društveni fenomen ili transformaciju nekog od postojećih, ispitivanje i promišljanje savremene društvene stvarnosti postaje još kompleksnije. Konzistentnost i adekvatnost teorijskog aparata koji društveni teoretičari koriste mora zadovoljiti uslov i teorijske koherentnosti, a to je bezmalo veliki izazov, kako u prethodnim epohama, tako i u današnjici. Zagorka Golubović i drugi su još sedamdesetih godina minulog veka $u$ analizi tada postojećih studija o strukturi jugoslovenskog društva isticali da je prilikom istraživanja društvene strukture važno imati sledeće na umu: 1) izgradnja i definicija konzistentnog pojmovnog aparata; 2) utvrđivanje kriterijuma i principa društvene diferencijacije; 3) refleksivnost da li se polazne pretpostavke i koliko temelje na iskustvenom saznanju; 4) analizu prirode 


\author{
Zbornik IKSI, 2-3/202O - A. Marković \\ „Prekarijat i neka pitanja društvene strukture i društvenih nejednakosti”, (str. 109-126)
}

podele rada u konkretnom društvu; 5) analizu preraspodele društvenog proizvoda; 6) utvrđivanje osnova društvenog raslojavanja, na koje se društvene grupe vrši raslojavanje i kakav je odnos među njima; 7) analiza postojanja društvenog sukoba među grupama zbog različitih interesa; 8) ulogu države; 9) utvrđivanje da li postoje protivrečnosti društvene strukture; 10) koje se društvene grupe kristalizuju kao pokretači društvenih promena, a koje su u ulozi održanja status-a quo (Golubović i drugi, 1977: 8-9). Jasno je da se i ovde vidi teorijsko određenje autorke i saradnika, no njihovo zapažanje je vredno i treba ga imati na umu bez obzira sa kojih pozicija polazimo. Kako bi Popović podvukao „bitno je da svaku klasu ili sloj lociramo na njeno istorijsko mesto, da shvatimo i objasnimo njene posebnosti koje proizlaze iz prirode globalnog društvenog sistema. (..) U svakom slučaju, rezultat takvog proučavanja trebalo bi da bude isti - dublje razumevanje i sociološko objašnjenje odgovarajućih oblika klasno-slojne podele društva“ (Popović, 1994: 95). Za kraj (a zapravo početak promišljanja i bavljenja prekarijatom), ako prekarijat realno postoji, važno je da li će biti određen kao klasa ili kao sloj ili kao nešto treće. Isto važi i za situaciju ukoliko se pokaže da je prekarijat teorijski neadekvatan pojam, jer se onda javlja pitanje njegove društvenonaučne i šire društvene upotrebe (upravo kao klase, sloja ili kao nečeg trećeg).

\title{
LITERATURA
}

(1) Antonić, S. (2009). Statusna analiza: dopuna ili alternativa klasne analize. Sociološki pregled, XLIII(4), 481-502. https://doi.org/10.5937/socprego904481A

(2) Alexander, J. (ed.) (1985). Neofunctionalism. Beverly Hills, CA: Sage Publications.

(3) Betti, E. (2016). Precarious Work: Norm or Exception of Capitalism? Historicizing a Contemporary Debate: A Global Gendered Perspective.In E. Betti and K. Miller (Eds.), The Power of the Norm. Fragile Rules and Significant Exceptions, Institut für die Wissenschaften vom Menschen, Junior Visiting Fellows' Conference, Vol. 35, 2016. (Published on the web, https://www.iwm.at/publications/5-junior-visitingfellows-conferences/vol-xxxv/precarious-work/)

(4) Bradley, H. (2014). Class Descriptors or Class Relations? Thoughts Towards a Critique of Savage et al.. Sociology, 48(3), 429-436.

https://doi.org/10.1177/0038038514520855

(5) Breman, J. (2013). A bogus concept? New Left Review, 84, 130-138. Dostupno na: https://newleftreview.org/issues/II84/articles/jan-breman-a-bogus-concept

(6) Cvejić, S. (2006). Korak u mestu. Društvena pokretljivost u Srbiji u procesu postsocijalističke transformacije. Beograd: Institut za sociološka istraživanja Filozofskog fakulteta. Dostupno na: http://isi.f.bg.ac.rs/wpcontent/uploads/2019/04/Slobodan-Cvejic-Korak-u-mestu.pdf

(7) Davis, K. \& Moore, W. (1945). Some principles of stratification. American Sociological Review, 1O(2), 242-249. https://doi.org/10.2307/2085643

(8) Đurić, M. (1964). Sociologija Maksa Vebera. Zagreb: Matica hrvatska.

(9) Evans, G. (1992). Testing the Validity of the Goldthorpe Class Schema. European Sociological Review, 8(3), 211-232. http://www.jstor.org/stable/522716

(10) Evans, G. \& Mills, C. (1998). Identifying Class Structure: A Latent Class Analysis of the Criterion-Related and Construct Validity of the Goldthorpe Class Schema. European Sociological Review, 14(1), 87-106. https://www.jstor.org/stable/522482 


\author{
Zbornik IKSI, 2-3/202O - A. Marković \\ „Prekarijat i neka pitanja društvene strukture i društvenih nejednakosti”, (str. 109-126)
}

(11) Evans, G. \& Mills, C. (200o). In Search of the Wage-Labour/Service Contract: New Evidence on the Validity of the Goldthorpe Class Schema. British Journal of Sociology, 51(4), 641-661. https://doi.org/10.1080/00071310020015307

(12) Frase, P. (2013). The Precariat: A Class or a Condition? New Labor Forum, 22(2), 11-14. https://doi.org/10.1177/1095796013482888

(13) Goldthorpe, J. H., \& Hope, K. (1972). Occupational grading and occupational prestige. Social Science Information, 11(5), 17-73. https://doi.org/10.1177/053901847201100502

(14) Goldthorpe, J. H. (1980). Social Mobility and Class Structure in Modern Britain. Oxford: Clarendon.

(15) Golubović, Z. i drugi. (1977). Analiza studija o strukturi jugoslovenskog društva. U: Supek, Rudi (ur.). Klase i slojevi: prilozi izučavanju društvenog sistema. Zagreb: Filozofki fakultet Sveučilišta - Odsjek za sociologiju.

(16) Gorc, A. (1982). Zbogom proletarijatu. Beograd: Radnička štampa.

(17) Grusky, D. (2001). Social Stratification. In S. Neil \& B. Paul (Eds.), International Encyclopedia of the Social \& Behavioral Sciences, Pergamon, 14443-14452.

(18) Grusky, D. \& Ku, M. (2008). Gloom, Doom, and Inequality. In Grusky, David B. (Ed.) Social Stratification: Class, Race, and Gender in Sociological Perspective. 3rd edition. Stanford University: Avalon Publishing.

(19) Haralambos, M. \& Holborn, M. (2002). Sociologija. Teme i perspektive. Zagreb: Golden marketing.

(20) Kalleberg, A. L. (2009). Precarious work, insecure workers: Employment relations in transition. American sociological review, 74(1), 1-22. https://doi.org/10.1177/000312240907400101

(21) Kerbo, H. R. (2007). Social stratification. In Bryant, C. D., Thomson G, \& Dennis L. P. 21st Century Sociology: A Reference Handbook. Gale Virtual Reference Library. Thousand Oaks, Calif: SAGE Publications.

(22) Lazić, M. (2011). Čekajući kapitalizam. Nastanak novih klasnih odnosa u Srbiji. Beograd: Službeni glasnik.

(23) Lazić, M. \& Cvejić, S. (prir.) (2019). Stratifikacijske promene u periodu konsolidacije kapitalizma u Srbiji. Beograd: Institut za sociološka istraživanja Filozofskog fakulteta u Beogradu. Dostupno na: http://isi.f.bg.ac.rs/wpcontent/uploads/2020/o1/Mladen-Lazi\%C4\%87-Slobodan-Cveji\%C4\%87-prirStratifikacijske-promene-u-periodu-konsolidacije-kapitalizma-u-Srbiji.pdf

(24) Marshall G. et al. (1988). Social Class in Modern Britain. London: Hutichinson.

(25) Marković, A. (2018). Prekarnost i migranti: prolazni izazov ili pretnja za sigurnosti stabilnost neoliberalizma. U Z. Lutovac \& S. Mrđa (Ur.) Savremene migracije $i$ društveni razvoj: interdisciplinarna perspektiva. Beograd: SSD, IDN, ISI Filozofski fakultet. Dostupno na: https://www.idn.org.rs/biblioteka/Zbornik_Migracije_Final_komplet.pdf

(26) Marković, A. \& Jovanović-Ajzenhamer, N. (2018). Klasično nasleđe savremenog fenomena: Veberovo shvatanje društvene stratifikacije i prekarijat. Kultura polisa, XV(37), 533-544. Dostupno na: https://kpolisa.com/KP37/KP37-IV$5 \% 20$ MarkovicJovanovic.pdf

(27) Marks, K. (2011). Osamnaesti brimer Luja Bonaparte. Beograd: Službeni glasnik.

(28) Marks, K. \& Engels, F. (1945). Manifest komunističke partije. Beograd: Biblioteka marksizma-lenjinizma, izdanje „Borbe“.

(29) Merton, R. (1998). O teorijskoj sociologiji. Beograd: Plato.

(30) Milić, V. (1996). Društvena struktura i pokretljivost Jugoslavije. Novi Sad: Filozofski fakultet, Katedra za sociologiju. 


\author{
Zbormik IKSI, 2-3/2020 - A. Marković \\ „Prekarijat i neka pitanja društvene strukture i društvenih nejednakosti”, (str. 109-126)
}

(31) Nemanjić, M. \& Spasić, I. (2006). Nasleđe Pjera Burdijea. Pouke i nadahnuća. Beograd: Institut za filozofiju i društvenu teoriju.

(32) Popović, M. (1994). Teorïa i empirïa. Sociološko istraživanje društvenih klasa i slojeva. Beograd: Institut za sociološka istraživanja Filozofskog fakulteta u Beogradu.

(33) Rose, D \& O'Reilly, K. (Eds.) (1997). Constructing Classes: Towards a New Social Classification for the UK. Swindon: ESRC/ONS.

(34) Ružica, M. (2015). Prekarizacija i prekarijat u Evropi. U S. Mihailović (Ur.) Od novinara do nadničara. Prekarizacija rada i života. Beograd: Fondacija za otvoreno društvo, Centar za razvoj sindikalizma.

(35) Saunders, P. (1990). Social Class and Stratification. London and New York: Routledge.

(36) Savage, M., Devine, F., Cunningham, N., Taylor, M., Li, Y., Hjellbrekke, J., ... \& Miles, A. (2013). A new model of social class? Findings from the BBC's Great British Class Survey experiment. Sociology, 47(2), 219-250. https://doi.org/10.1177/0038038513481128

(37) Standing, G. (2011). The Precariat: The New Dangerous Class. London: Bloomsbury Academic. https://doi.org/10.5040/9781849664554

(38) Starčević, M. (2014). Prekarni rad i nemogućnost prekarne klase. Diskrepancija: studentski časopis za društveno-humanističke teme, 13(19), 37-57. Dostupno na: https://hrcak.srce.hr/129223

(39) Strasser, H. (1980). Stratum and Class Formation: Principles of a Theory of Social Inequality. The Canadian Journal of Sociology / Cahiers canadiens de sociologie, 5(2), 103-120. https://doi.org/10.2307/3339951

(40) Supek, R. (1961). Ispitivanje javnog mnjenja. Zagreb: Naprijed.

(41) Supek, R. (1977a). Marxovo određenje pojma društvene klase i teorijsko osporavanje tog pojma. U R. Supek (Ur.). Klase i slojevi: prilozi izučavanju društvenog sistema. Zagreb: Filozofski fakultet Sveučilišta - Odsjek za sociologiju.

(42) Supek, R. (1977b). Prilog diskusiji o stratifikaciji i klasama. U R. Supek (Ur.). Klase i slojevi: prilozi izučavanju društvenog sistema. Zagreb: Filozofski fakultet Sveučilišta - Odsjek za sociologiju.

(43) Veber, M. (1976). Privreda i društvo, knj. 2. Beograd: Prosveta.

(44) Warner, W. L., Meeker, M., \& Eells, K. (1949). Social class in America; a manual of procedure for the measurement of social status. Chicago: Science Research Associates.

(45) Wright, E. O. (ed.) (2005). Approaches to Class Analysis. Cambridge: Cambridge University Press.

(46) Wright, E. O. (2015). Understanding Class. London: Verso.

(47) Wright, E. O. (2016). Is the Precariat a Class? Global Labour Journal, 7(2), 123135. https://doi.org/10.15173/glj.v7i2.2583 


\section{PRECARIAT AND SOME SOCIAL STRUCTURE AND SOCIAL INEQUALITIES ISSUES}

The justification for introducing a still relatively new notion of precariat to scientific knowledge fund is an issue that requires special analysis and argumentation. Nevertheless, regardless of which theoretical point of view we take, members of the precariat (or individuals in a very precarious position in modern societies) do not levitate independently from each other and the other social groups. Therefore, this paper aimed primarily to provide readers with a brief overview of the complexity of probing social structure and systems, mostly through an overview of the basic theoretical ways of studying social stratification and inequality. Hence, it should open the question whether and how precariat could be epistemological and methodologically questioned in the social stratification surveys. Also, it should open the question of whether and how the precariat could be epistemological and methodologically questioned in the social stratification surveys. The article also offers an overview and a critique of one of the still most influential empirical studies of social structure, in which the precariat is recognized as one of the social groups that create the structure of British society (BBC’s Great British Class Survey, 2011).

KEYWORDS: Precariat / Social structure / Social stratification / Social inequalities 